\title{
Predictors of intentions to participate in politics and actual political behaviors in young adulthood
}

\author{
Katharina Eckstein,' Peter Noack,' and Burkhard Gniewosz ${ }^{2}$
}

\begin{abstract}
Drawing on data from a three-wave longitudinal study, the present research examined predictors of young adults' intentions to participate in politics and their actual political activities while referring to the broader assumptions of the theory of planned behavior. The analyses were based on a sample of university students from the federal state of Thuringia, Germany. The results showed that attitudes toward political behaviors and internal political efficacy beliefs explained changes in students' intentions to participate in politics. However, the perceived meaning that political participation has for important others had no additional effect. Furthermore, students' intentions to participate in politics and their internal political efficacy beliefs predicted changes in their actual behaviors. Together, the findings supported the theory of planned behaviors as a useful framework helping to predict young adults' intentions and actual involvement in political activities.
\end{abstract}

\section{Keywords}

internal political efficacy, political behaviors, political participation, theory of planned behaviors, young adulthood, young people

What motivates young people to become active citizens? Over the past decades, this question has been frequently discussed and still is in the focus of many public debates. Certainly, political involvement might include a broad array of different activities. In this regard, conventional or traditional forms of political involvement (e.g., joining political parties) are generally distinguished from unconventional forms of involvement, such as demonstrating or signing petitions (Barnes et al., 1979). Even though young people approve of several forms of political involvement, research has indicated that participation is rather rare when it comes to more traditional forms of involvement (Syvertsen, Wray-Lake, Flanagan, Osgood, \& Briddell, 2011; Torney-Purta, Lehmann, Oswald, \& Schulz, 2001). Considering this finding, a better understanding of the processes underlying political participation is of particular importance. Although a variety of predictors of (intentions toward) political behaviors have already been identified by previous studies, they mostly lack a solid theoretical foundation (Wilkenfeld, Lauckhardt, \& Torney-Purta, 2010). Therefore, it was the goal of the present study to select theory-based predictors of young people's conventional political participation drawing on the broader assumptions of the theory of planned behavior (TPB; Ajzen, 1991; Ajzen \& Madden, 1986), which has been shown to be a valid framework in predicting a broad spectrum of human behaviors (for an overview, see Fishbein \& Ajzen, 2010).

We conducted this research based on a sample of young adult university students. Particularly in industrialized countries, the young adulthood years are characterized by numerous changes, such as the encounter of new contexts or roles (e.g., entering tertiary education, moving out of parental home) and an intensive identity exploration (cf. Arnett's notion of emerging adulthood; Arnett, 2000; Kroger, 2007). Moreover, it is not until young adulthood that young people acquire all rights and responsibilities of citizenship. This applies especially to conventional politics (e.g., voting in elections, joining political parties). Therefore, young adulthood has been identified as one important time when political values and positions are shaped (Finlay, Wray-Lake, \& Flanagan, 2010; cf. impressionable years hypothesis; Sears \& Levy, 2003). Hence, it is important to understand predictors and processes leading to political participation during this period in life.

According to the TPB's main assumptions, an immediate predictor of a behaviors is the intention to perform the respective behaviors. The behavioral intention, in turn, can be explained by three proximal factors: (1) attitudes toward the behavior, (2) the perception of important others' approval of the behavior (subjective norm), and (3) the perceived behavioral control. According to Ajzen (1991), the perceived behavioral control might affect behaviors even directly and beyond its effect on the behavioral intention, if the behavior is highly dependent on internal (e.g., competencies) or external (e.g., opportunities) requirements. In applying these theoretical assumptions to established concepts from political participation research, three main predictors were in the focus of the present study: Attitudes toward political behaviors, important others' attitudes toward political behaviors, and internal political efficacy beliefs.

Drawing on these theoretical considerations, it can be assumed that the conscious decision to become involved in political activities corresponds to a positive evaluation or approval of the respective

\footnotetext{
I Friedrich-Schiller-University Jena, Germany

${ }^{2}$ Ludwig-Maximilians-University Munich, Germany

\section{Corresponding author:}

Katharina Eckstein, Department of Educational Psychology, FriedrichSchiller-University Jena, Humboldtstr. 27, Jena 07743, Germany.

Email: katharina.eckstein@uni-jena.de
} 
behavior (i.e., attitude toward behavior). Indeed, with respect to young people's political involvement, several studies showed that attitudes and (intentions concerning) political participation are interrelated (e.g., Benton et al., 2008; Jülisch, 1996; Pancer, Pratt, Hunsberger, \& Alisat, 2007). Yet, political orientations surely do not develop in a social vacuum. Rather, they are related to experiences within different social contexts, as for example family or peers. Correspondingly, contextual models of human development, such as Bronfenbrenner's ecological systems theory (1979), underline that individual development cannot be investigated separately from contextual influences (Sameroff, 2010). Generally, important others affect young people's political participation in several ways: Besides explicit discussions, being a role model, or providing access to social networks (Marzana, Marta, \& Pozzi, 2012; Oswald \& Schmid, 2006; Verba, Schlozman, \& Burns, 2005; Zaff, Malanchuk, \& Eccles, 2008), the approval of political behaviors expressed by close persons is another important influencing factor (e.g., Da Silva, Sanson, Smart, \& Toumbourou, 2004; Fletcher, Elder, \& Mekos, 2000). TPB introduces the subjective norm as a crucial kind of social influence.

Finally, one essential finding in the field of social science is that a person's sense of efficacy affects his or her motivation to act (cf. social cognitive theory; Bandura, 1986, 1997). According to Bandura (1986), self-efficacy denotes “people's judgments of their capabilities to organize and execute courses of action required to attain designated types of performances" (p. 391). Bandura (1995) also summarized several sources that facilitate the development of self-efficacy beliefs, such as mastery experiences, seeing other people acting successfully, or receiving positive feedback. Within the TPB, the importance of self-efficacy beliefs is reflected in the concept of perceived behavioral control, more precisely in its dimension of perceived self-efficacy (i.e., perceived ability to carry out a certain behavior; Ajzen, 2002b). Applied to the political domain, the concept of internal political efficacy appears to be of particular importance. It has been defined as the perceived competence to understand and to participate effectively in politics (Niemi, Craig, \& Mattei, 1991) and has also been conceptually related to the notion of self-efficacy (e.g., Richardson, 2003; Vecchione \& Caprara, 2009). Accordingly, people who feel confident when it comes to politics and think their actions can make a difference are more likely to become politically engaged (Beaumont, 2010). In fact, across different national contexts and age groups, internal political efficacy beliefs were found to be a strong predictor of the intended and actual involvement in various political activities (Gastil \& Xenos, 2010; Krampen, 1998; Vecchione \& Caprara, 2009). Given this importance, political participation research strived for a better understanding of pathways leading to internal political efficacy. According to Bandura (1995), one possible way is having positive experiences within the political domain. Indeed, among U.S. college students such positive political learning experiences (e.g., summer institutes, politically-related internship programs, extra curricular programs) were found to strengthen internal political efficacy beliefs (cf. Beaumont, 2010, 2011; Colby, Beaumont, Ehrlich, \& Corngold, 2007). Correspondingly, research generally assumes a reciprocal relation between internal political efficacy and political participation. In line with this reasoning, TPB does not negate the importance of past experiences which, in turn, are also assumed to affect attitudes, subjective norms, and the perceived behavioral control (Ajzen, 1991).

Even though the TPB has already been applied to predict political behaviors, such as voting (Glasford, 2008; Netemeyer \&
Burton, 1990), peace activities (Fox-Cardamone, Hinkle, \& Hogue, 2000), women's rights activities (Kelly \& Breinlinger, 1995), or environmental activities (Fielding, McDonald, \& Louis, 2008), the present study goes beyond previous research in several aspects: While research on political participation mostly focused either on the intention or the behavior, we aimed at explaining both behavioral intentions and actual political behaviors. In doing so, we were able to test multiple tenets of the theory simultaneously. Moreover, our theory-based assumptions are tested in a longitudinal design which allows for a stronger test of the hypothesized relationships and, therefore, helps to provide a better understanding of the processes underlying political behaviors.

\section{The present study}

Following the broader assumptions provided by the TPB, the aim of the present study was threefold: First, we examined whether attitudes toward political behaviors, the perceived attitudes toward political behaviors of important others (subjective norm), and internal political efficacy (perceived behavioral control) would explain changes in young adults' intentions to participate in conventional political activities (behavioral intention according to TPB; research question 1). Second, we assessed whether young adults' intentions to participate in politics would predict their political activities at a later measurement point (research question 2). Third, following the assumption of the TPB that the perceived behavioral control might even affect behaviors directly, we examined whether young adults' internal political efficacy would also directly predict the amount of actual activities (research question 3). Finally, each of these research questions was examined while controlling for the effects of socio-structural variables (i.e., age and gender).

\section{Method}

\section{Sample}

The present study is based on data from a longitudinal survey on political attitudes in young adulthood. Students from a mediumsized university located in the federal state of Thuringia, Germany ${ }^{1}$ were surveyed three times over a period of 1 year (Time 1: April 2008; Time 2: October 2008; Time 3: April 2009). We chose a time gap of 6 months between each measurement occasion because it corresponds to one semester in Germany. Moreover, the fact that the university years involve many changes (e.g., place of residence, social life) supported the decision for a shorter time gap. The sample comprised 428 young adults with more females $(n=291$, $68.0 \%)$ than males $(n=137,32.0 \%)$ participating in the survey. The mean age at Time 1 was 21.33 years $(S D=2.57$, age range: 17-33; T2: $M_{\text {age }}=21.79, S D=2.54$, age range: $17-33 ; \mathrm{T} 3$ : $M_{\text {age }}=22.33, S D=2.44$, age range: $\left.18-34\right)$. The overall number of completed semesters ranged between 1 and $12(M=4.00$, $S D=2.10$ ). Participants came from various majors, such as economics, humanities, social science, and natural science, in order to reflect a student body as broad as possible. At the initial assessment, participants were contacted in lectures and seminars and asked to fill out a paper-pencil questionnaire on different political topics. Since it would have been extremely difficult to contact each of the participants at the end of the semester in their changing courses, the following two assessments were conducted via an online survey. As an incentive for the participation in the survey several gift certificates 
Table I. Intercorrelations, means, and standard deviations.

\begin{tabular}{|c|c|c|c|c|c|c|c|}
\hline Measure & 1 & 2 & 3 & 4 & 5 & 6 & 7 \\
\hline I. Attitudes toward political behaviors T2 & - & & & & & & \\
\hline 2. Important others' attitudes toward political behaviors T2 & $.67 * * *$ & - & & & & & \\
\hline 3. Internal political efficacy T2 & $.45 * * *$ & $.45^{* * *}$ & - & & & & \\
\hline 4. Intentions to participate in politics $\mathrm{TI}$ & $.50 * * *$ & $.45^{* * *}$ & $.58 * * *$ & - & & & \\
\hline 5. Intentions to participate in politics $\mathrm{T} 2$ & $.64 * * *$ & $.57^{* * *}$ & $.66 * * *$ & $.70 * * *$ & - & & \\
\hline 6. Political behavior $\mathrm{TI}$ & $.33 * * *$ & $.29 * *$ & $.42 * * *$ & $.60 * * * *$ & $.52^{* * * *}$ & - & \\
\hline 7. Political behavior $\mathrm{T} 3$ & $.30 * * *$ & $.31 * * *$ & $.46 * * *$ & $.46 * * *$ & $.51 * * *$ & $.70 * * * *$ & - \\
\hline 8. Age & .03 & -.04 & .03 & .09 & $.15^{*}$ & $.15^{* *}$ & $.15^{\text {** }}$ \\
\hline 9. Gender & $-.14^{* * *}$ & -.05 & $-.37^{* * *}$ & $-.26 * * *$ & $-.26 * * *$ & $-.16 * *$ & $-.17^{* *}$ \\
\hline M & 4.17 & 3.54 & 3.51 & 2.76 & 3.28 & 0.62 & 0.77 \\
\hline$S D$ & 0.82 & 0.77 & 1.16 & 0.96 & 0.92 & 0.88 & 0.87 \\
\hline
\end{tabular}

Note. $* * * p<.001 ; * * p<.01 ; * p<.05$.

were given to randomly selected participants after each assessment. The implications of this sampling procedure will be discussed.

\section{Measures}

Four items were used to examine students' intentions to participate in conventional political activities ("I would ... work for a political party, support a political candidate, visit political debates, contact politicians;" Cronbach's alpha $=.77$ ). The students were also asked to indicate whether they have already participated in any of these political activities (i.e., actual behavior). Attitudes toward political behaviors were assessed with four items (e.g., "There are not too many, but too few people politically active in Germany;" Fischer \& Kohr, 2002; Cronbach's alpha $=.73$ ). Moreover, four items were used to capture young adults' perceptions of important others' attitudes toward political behaviors (e.g., "People in my life whose opinions I value would approve, if I were politically engaged;" adapted from Ajzen, 2002a; Cronbach's alpha = .79). Finally, participants' sense of internal political efficacy was also assessed by four items (e.g., "I consider myself well qualified to participate in politics;" Niemi et al., 1991, Cronbach's alpha = .88). The complete item wordings are presented in the appendix.

Except for the assessment of actual political behaviors $(0=n o$, $1=y e s)$, the response options ranged from $1=I$ do not agree at all to $6=$ I totally agree. Finally, gender was coded $0=$ male and $1=$ female.

\section{Attrition}

Before examining the research questions of the present study, a closer analysis of missing values was carried out. As part of the longitudinal design of the study, not all students continued to participate in the survey (complete data: $n=324,75.4 \%$ of initial sample). Comparing the two subgroups of students with and students without missing data revealed no significant differences concerning intentions to participate in politics, $t(426)=1.46, p=.15, d=.14$, actual political behaviors, $t(426)=1.31, p=.19, d=.13$, attitudes toward political behaviors, $t(426)=1.78, p=.08, d=.17$, important others' attitudes toward political behaviors, $t(426)=0.91, p=$ $.36, d=.09$, and internal political efficacy, $t(426)=1.67, p=.10, d$ $=.16$. Also, with respect to the examined socio-structural variables - age and gender - no differences occurred; age: $t(426)=1.42, p=$ $.15, d=.14$; gender: $\chi^{2}(1, N=428)=0.68, p=.72$. Nevertheless, to prevent a further reduction of the initial sample size, missingness was taken into account using a MLR estimation (maximum likelihood estimation with robust standard errors) that is comparable to the full information maximum likelihood approach. Thus, cases with missing data were not excluded, but all model parameters were estimated based on the cases with complete data and the (conditional) missing values under the missing at random assumption. Instead of using listwise deletion, the latter has shown to be a more appropriate method of dealing with missingness, since it prevents the common disadvantages such as losing statistical power or biased parameter estimation (Graham, 2009; Jeličič, Phelps, \& Lerner, 2009).

\section{Results}

Structural equation modelling (SEM) was applied using Mplus 6 (Muthén \& Muthén, 1998-2010) which allowed us to investigate variable relationships at a latent level. In order to apply latent SEM, while keeping the model at a limited amount of complexity, item parcels were constructed for each scale. Item parcelling has also shown to be advantageous regarding the accuracy of parameter estimates, model fit, and reliability. Moreover, item parcelling can lead to a distribution that is similar to a normal distribution, especially for larger scaled items (for an overview, see Bandalos, 2002). All constructs were measured by two parcels. Items were allocated to parcels according to their factor loadings so that each parcel had a similar relation to the latent construct (cf. Little, Cunningham, Shahar, \& Widaman, 2002).

The intercorrelations, means, and standard deviations for all variables are shown in Table 1. Two models were specified in order to test our assumptions.

In Model 1, students' intentions to participate in politics at Time 2 were predicted by attitudes toward political behaviors, important others' attitudes, and internal political efficacy at Time 2. Intentions to participate in politics were controlled for their Time 1 assessment, so Time 2 predictors could explain changes in the dependent variable (research question 1). Correlations among the latent exogenous constructs were permitted. The extent of actual political activities was also included in the analysis. To account for past and future political activities, political behaviors reported at Time 1 and Time 3 were considered. In addition to the above-described relationships, the effects of young adults' political behaviors at Time 1 on their behavioral intentions at Time 2 as well as correlations between political behaviors at Time 1 and students' behavioral intentions at Time 1, their attitudes toward political behaviors, the 


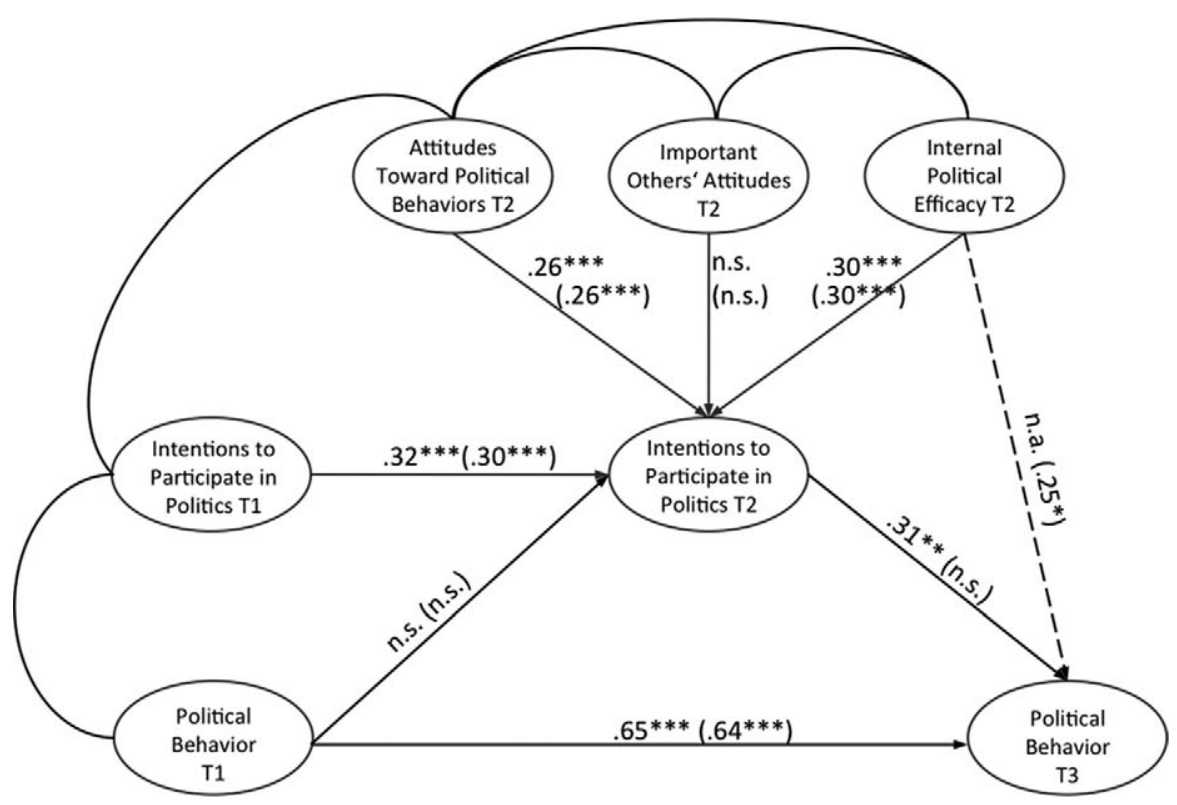

Figure I. Graphical depiction of Model I and Model 2 (addition of Model 2 indicated by dashed arrow). Coefficients represent standardized path coefficients of Model I and Model 2 (latter coefficients in parentheses).

Note. ${ }^{* * *} p<.001 ;{ }^{*} p<.01 ;{ }^{*} p<.05$, n.s. $=$ not significant, n.a. $=$ not assessed.

perceived attitudes of important others, and internal political efficacy at Time 2 were permitted. Students' political behaviors at Time 3 were regressed on their political behaviors at Time 1 and behavioral intentions at Time 2 (research question 2). Furthermore, gender and age were added to the model, whereby each of the examined constructs was predicted by the two socio-structural variables. A graphical depiction of the model is given in Figure 1. To keep the graphical depiction at a manageable amount of complexity, the results of the socio-structural variables are not displayed in Figure 1.

Overall, Model 1 showed a good fit to the data, $\chi^{2}(63, N=428)=$ $98.67, p=.00, \mathrm{CFI}=.99, \mathrm{TLI}=.97$, and RMSEA $=.04$. The correlational relationships indicated that students' political behaviors at Time 1 were not only positively related to their behavioral intentions at Time 1 (std. coefficient $=.56, S E=.06, p<.001$ ), but also to attitudes (std. coefficient $=.27, S E=.07, p<.001$ ), the perceived attitudes of important others (std. coefficient $=.24, S E=$ $.08, p=.002$ ), and their sense of internal political efficacy (std. coefficient $=.33, S E=.06, p<.001$ ) at Time 2 . Addressing the study's first research question, the results revealed that after controlling for behavioral intentions at Time 1 (std. coefficient $=$ $.32, S E=.09, p<.001)$, both attitudes toward political behaviors (std. coefficient $=.26, S E=.06, p<.001)$ and internal political efficacy (std. coefficient $=.30, S E=.06, p<.001$ ) explained changes in young adults' intentions to participate in politics. Yet, the perceived attitudes of important others had no additional effect (std. coefficient $=.12, S E=.07, p=.11$ ). In answering the second research question, the results revealed that young adults' intentions to participate in politics at Time 2 predicted changes in their actual behaviors at Time 3 (std. coefficient $=.31, S E=.12, p=.008$ ), even after controlling for political activities at Time 1 (std. coefficient $=.65, S E=.13, p<.001)$. The results of the background variables pointed to a small effect of age on young adults' intentions to participate in politics at Time 2 (std. coefficient $=.10$, $S E=.04, p=.003$ ), indicating that older students reported higher levels of agreement. With respect to gender, the results revealed a negative effect on students' internal political efficacy (std. coefficient $=-.40, S E=.04, p<.001)$, attitudes toward political behaviors (std. coefficient $=-.13, S E=.05, p=.02$ ), and intentions to participate in politics at Time 1 (std. coefficient $=-.23, S E=.05$, $p<.001$ ). Thus, male students reported higher levels of agreement on these variables.

In a second model, political behaviors at Time 3 were additionally predicted by students' internal political efficacy at Time 2 (research question 3; see dashed line in Figure 1). Apart from this, the model specifications were the same as described for Model 1. The model also showed a good fit to the data, $\chi^{2}(62, N=428)=$ 93.33, $p=.01, \mathrm{CFI}=.99$, TLI $=.98$, and RMSEA $=.03$. The results revealed that, controlled for political activities at Time 1, students' internal political efficacy predicted changes in their political behaviors at Time 3 (std. coefficient $=.25, S E=.11, p=.03$ ). Neither for attitudes nor for the perceived attitudes of important others was this direct path significant. Yet, when accounting for this effect, the influence of intentions to participate in politics at Time 2 on political activities at Time 3 was no longer significant (std. coefficient $=.13, S E=.13, p=.32$ ). All other parameter estimates, however, remained basically the same as in Model 1 (see Figure 1). Since Model 1 and 2 were nested, a subsequent $\chi^{2}$-difference test was carried out. ${ }^{2}$ The results showed that Model 2 (i.e., unconstrained model) fit the data significantly better, $\chi^{2} \Delta(1,428)=7.78, p=.01$.

Considering the often cited gender differences, especially for conventional political behaviors, in a last step we tested for potential moderator effects. The results indicated that the constrained model (parameter estimates constrained to be equal across male and female subgroup) did not fit the data significantly worse than the unconstrained model (parameter estimates allowed to vary across the two groups), $\chi^{2} \Delta(17,428)=16.70, p=.47^{2}$. Thus, the model with equal parameter estimates for males and females was not rejected. Since age was included as a second covariate in our model, we also tested whether the model might differ when comparing 
younger $\left(M_{\text {age }} \leq 22 ; n=247\right)$ and older students $\left(M_{\text {age }} \geq 23 ; n=\right.$ 181). Again, the $\chi^{2}$-difference test was non-significant, $\chi^{2} \Delta(17,428)=22.90, p=.15^{2}$, indicating that the more parsimonious model with equal parameter estimates across the two age groups (constrained model) could be maintained.

\section{Discussion}

Drawing on the broader framework of the theory of planned behavior, the present study pursued the goal to explain young adults' (intentions toward) conventional political behaviors. With our first research question, we found that both attitudes toward political behavior and internal political efficacy beliefs explained changes in young adults' intentions to participate in politics. Whereas this finding was in line with the theoretical assumptions, the perceived attitudes toward political behaviors of important others had no additional significant effect. Even though this result pattern was also reported by other studies based on the theory of planned behavior (e.g., Ajzen \& Madden, 1986; for a metaanalytic overview, see Armitage \& Conner, 2001), simply concluding that social influences are less meaningful in explaining behavioral intentions would be premature. Concerning the prediction of political behaviors, the results are not unanimous. While some studies found no significant influence of subjective norms (e.g., Fox-Cardamone et al., 2000; Netemeyer \& Burton, 1990), others found significant effects (Fielding et al., 2008; Kelly \& Breinlinger, 1995). Yet, since most studies differ in terms of design, conceptualization, and measurement, it is difficult to draw generalizing conclusions.

Rather, one possible explanation for the results of the present study might be provided by the consideration of perceptual processes. That is, according to Westholm (1999), important others' attitudes need to be accurately perceived in order to exert influence. Hence, if concentrating on the perceived attitudes of important others only, as we did in the present study, it cannot be ruled out that due to a lack of accurate perception young people project their own attitudes onto their friends, parents, romantic partners, etc. (e.g., Gniewosz \& Noack, 2006; Westholm, 1999). This might have led to the high concordance between students' own attitudes and their perception of important others' attitudes toward political behaviors (see, zero-order correlation in Table 1). This process, in turn, might have contributed to the finding that the perceived attitudes of important others had no additional effect beyond the examined individual predictors. Hence, to address this issue in more detail, future research accounting for both important others' actual political attitudes, behaviors and how young people perceive them would be desirable.

Moreover, while the approval of political behaviors by important others represents one possible way of influence, it is certainly not the only kind of a social predictor. As, for example, research on political discussions and controversies has demonstrated, sometimes it is also important others' diverse opinions that affect young people's political behaviors (e.g., Hess, 2009; Richardson, 2003). Thus, future studies should consider a more thorough investigation of different kinds of social influences.

Addressing the study's second and third research question, the extent of actual political activities was taken into account. Although students' intentions to participate in politics predicted their political activities at a later measurement point (research question 2), their internal political efficacy was found to be an even stronger predictor. As the results of Model 2 indicated the effect of students' behavioral intentions was no longer significant, once internal political efficacy beliefs were taken into account (cf. research question 3).

This finding, however, does not contradict the theoretical assumptions. That is, according to Ajzen (1991),

both, intentions and perceptions of behavioral control, can make significant contributions to the prediction of behavior, but in any given application, one may be more important than the other and, in fact, only one of the two predictors may be needed. (p. 185)

The latter seems to be the case in this study. One possible explanation for this finding might be the considered types of participation. That is, most of the examined activities (e.g., working for a political party) place high demands on the students. Consequently, students who are motivated to meet these requirements might already possess a strong feeling of political abilities and action competencies (i.e., internal political efficacy). Statistically, this was reflected in the substantial correlation between students' internal political efficacy and their intentions to participate in conventional politics (see, zero-order correlation in Table 1). Hence, to a large extent both variables explained the same variance in students' actual political behaviors. This, in turn, might have led to the finding that when taking into account both students' internal political efficacy and their intentions to participate in politics, the latter no longer predicted subsequent political behaviors independently.

From a practical perspective, this finding underlines the particular importance of internal political efficacy beliefs for the involvement in conventional politics. That is, the mere intention is not always sufficient. Rather, the decision to become involved seems to be even more dependent on the perception whether one has the ability to make meaningful contributions. However, other forms of political participation which require less personal capabilities, such as signing a petition or voting in elections, might be less dependent on a person's beliefs about his or her political competencies. Therefore, future research should examine in how far this pattern of findings varies across different types of political behaviors.

In addition to the examination of individual and social influences, we controlled for the effects of the socio-structural variables age and gender: Considering gender differences, male participants reported higher levels of agreement for intentions to participate in politics, attitudes toward political behaviors, and internal political efficacy. This pattern generally fits the existing literature on gender differences indicating that especially traditional politics is rather seen as a "man's game" (Alozie, Simon, \& Merril, 2003; Kuhn, 2010). Age differences were only found for young adults' intentions to participate in politics at Time 2 . The absence of more age differences might be related to the fact that the study concentrated on the examination of university students only and therefore a rather narrow age range.

Finally, some methodological issues of this study need to be discussed. At first, it has to be pointed out that even though the prediction of behavioral intentions by variables assessed at the same measurement point (i.e., Time 2) allowed us to depict rather proximal or contemporary processes, it does not allow for making any strict conclusions about directional relationships. That is, although controlling for the stability of young adults' intentions to participate in politics provided more information as compared to traditional cross-sectional designs, longitudinal predictions would be desirable in future studies. The latter, however, was not possible in the present study, since several variables were not available before the 
second measurement point (e.g., important others' attitudes toward political behaviors, internal political efficacy). In contrast to these proximal predictors, the theory of planned behavior assumes that past behaviors are rather distant factors. Therefore, we included students' political activities at Time 1 to control for the stability of political behaviors.

Second, the characteristics of the sample should be taken into account. Since the study was carried out at an East German university, the question of representativeness emerges, especially against the backdrop of the recent German history (for an overview of the consequences of German unification, see Silbereisen, 2005). With respect to conventional political activism, national surveys indicated less involvement among young people from the "New States" (cf. Weßels, 2008), which underlines the importance to account for regional differences. It should be noted, though, that regional differences vary across political domains and are mostly much smaller than the gaps found between generations, for example (Weßels, 2008). Finally, even though the present study was conducted at an East German university, not all students were born and grew up in East Germany. That is, approximately $20 \%$ of the participants $(n=80)$ had recently moved to the eastern part of Germany to attend university.

Moreover, the present study was based on a convenience sample of university students. Although we tried to examine a student body as broad as possible, we cannot rule out potential selection effects in terms of fields of study, gender, and motivation to participate in the survey. Female students, for example, were overrepresented. Despite the variety of subjects, this finding showed to be related to the examined fields of studies. That is, apart from the humanities, the subjects of psychology and medicine, which constituted the largest part of the sample, were more frequently attended by female students. Hence, to make more sustained statements about the generalizability of our findings, further research which considers participants from different educational, regional, and national backgrounds would be desirable.

Third, whereas at the first measurement point students filled out a paper-and-pencil questionnaire, the subsequent assessments were carried out by means of an online-survey. Yet, despite the change in modalities research indicates that these two forms of data collection do not differ in reliability and validity of the examined constructs (Cronk \& West, 2002). Moreover, carrying out online-surveys also had a decisive advantage. That is, irrespective whether students changed their subject or were simply not present at a given class, all participants could be reached.

So far, we primarily concentrated on the examination of predictors of young adults' (intentions toward) political behaviors. Yet, positive political experiences, be it in the context of a student council or a local political organization, have also shown to strengthen students' political beliefs, such as their sense of internal political efficacy (Beaumont, 2010). In addition, such experiences might also convince students of the necessity to play an active role in the public sphere. As our results indicated, past behaviors were indeed related to young adults' attitudes toward political behaviors, the perception of important others' attitudes, and internal political efficacy beliefs. Overall, it is to expect that there is a permanent process of reciprocity between individual beliefs and political behaviors. Yet, due to the restricted longitudinal design and the theoretical rational of our study, we did not pursue this question in more detail. Therefore, future research, examining a longer period of time, should take a closer look at these reciprocal relations.
Referring back to our initial question "what motivates young people to become active citizens?" the present research yielded some instructive findings. Overall, the theory of planned behavior has shown to be a useful theoretical framework helping to provide a better understanding of why some young adults are more inclined to become involved in conventional politics than others. Especially internal political efficacy beliefs were shown to play a crucial role at this period in life. It is the knowledge of these processes that enables teachers, politicians, or researchers to take action. Supporting the application of practical approaches that enhance these individual beliefs, for example in the context of university courses or extracurricular experiences, could represent one practical and concrete way to bring young people closer to the political sphere (cf. Beaumont, 2011; Colby et al., 2007; Pasek, Feldman, Romer, \& Jamieson, 2007; Sylvester, 2010).

\section{Acknowledgements}

This research was supported by the German Research Foundation (DFG, FOR 481, No 213/9-4) by financial aid given to the second and third author.

\section{Notes}

1. In terms of demographic characteristics, such as students' age or socio-economic background, the student body of the FriedrichSchiller-University Jena is comparable to other German universities. Most German universities are public and therefore require no or only a small amount in tuition fees, which reduces selection effects due to students' socio-economic background. For some subjects, such as psychology or medicine, however, there is a restricted admission, which varies between universities. Criteria of selection are mostly students' Abitur grades (high school diploma). Within this study, we tried to include students from different subjects in order to reflect a broad student body, thereby reducing possible selection effects.

2. To account for the MLR estimation of the present analyses, this difference test was conducted using the log-likelihood values and the MLR scaling correction factors. The test statistic of this difference test is also chi-square distributed.

\section{References}

Ajzen, I. (1991). The theory of planned behavior. Organizational Behavior and Human Decision Processes, 50(2), 179-211. doi:10.1016/ 0749-5978(91)90020-T

Ajzen, I. (2002a). Constructing a TPB questionnaire: Conceptual and methodological considerations. Retrieved from http://www.people. umass.edu/aizen/pdf/tpb.measurement.pdf

Ajzen, I. (2002b). Perceived behavioral control, self-efficacy, locus of control, and the theory of planned behavior. Journal of Applied Social Psychology, 32(4), 665-683. doi:10.1111/j.1559-1816. 2002.tb00236.x

Ajzen, I., \& Madden, T. J. (1986). Prediction of goal-directed behavior: Attitudes, intentions, and perceived behavioral control. Journal of Experimental Social Psychology, 22(5), 453-474. doi:10.1016/ 0022-1031(86)90045-4

Alozie, N. O., Simon, J., \& Merril, B. D. (2003). Gender and political orientation in childhood. The Social Science Journal, 40(1), 1-18. doi:10.1016/S0362-3319(02)00255-0

Armitage, C. J., \& Conner, M. (2001). Efficacy of the theory of planned behavior: A meta-analytic review. British Journal of Sociology, 40(4), 471-499. doi:10.1348/ 014466601164939 
Arnett, J. J. (2000). Emerging adulthood: A theory of development from the late teens through the twenties. American Psychologist, 55(5), 469-480. doi:10.1037//0003-066X.55.5.469

Bandalos, D. L. (2002). The effects of item parceling on goodness-of-fit and parameter estimate bias in structural equation modeling. Structural Equation Modeling, 9(1), 78-102. doi:10.1207/S15328007S EM0901_5

Bandura, A. (1986). Social foundations of thought and action: A social cognitive theory. Englewood Cliffs, NJ: Prentice-Hall.

Bandura, A. (1995). Self-efficacy in changing societies. New York, NY: Cambridge University Press.

Bandura, A. (1997). Self-efficacy: The exercise of control. New York, NY: W. H. Freeman.

Barnes, S. H., Kaase, M., Allerbeck, K. R., Farah, B. G., Heunks, F., \& Ingelhart, R., ... Rosenmayr, L. (1979). Political action: Mass participation in five Western democracies. Beverly Hills, CA: SAGE.

Beaumont, E. (2010). Political agency and empowerment: Pathways for developing a sense of political efficacy in young adults. In L. R. Sherrod, J. Torney-Purta \& C. A. Flanagan (Eds.), Handbook of research on civic engagement in youth (pp. 525-558). Hoboken, NJ: Wiley.

Beaumont, E. (2011). Promoting political agency, addressing political inequality: A multilevel model of internal political efficacy. The Journal of Politics, 73(1), 216-231. doi:10.1017/S002238161000 0976

Benton, T., Cleaver, E., Featherstone, G., Kerr, D., Lopes, J., \& Whitby, K. (2008). Citizenship education longitudinal study (CELS): Sixth annual report. Young people's civic participation in and beyond school: Attitudes, intentions, and influences (DCSF Research Report 052). London, UK: DCSF.

Bronfenbrenner, U. (1979). The ecology of human development: Experiments by nature and design. Cambridge, MA: Harvard University Press.

Colby, A., Beaumont, E., Ehrlich, T., \& Corngold, J. (2007). Educating for democracy: Preparing undergraduates for responsible political engagement. San Francisco, CA: Jossey-Bass.

Cronk, B. C., \& West, J. L. (2002). Personality research on the internet: A comparison of web-based and traditional instruments in take-home and in-class settings. Behavior Research Methods, Instruments, \& Computers, 34(2), 177-180. doi:10.3758/BF03195440

Da Silva, L., Sanson, A., Smart, D., \& Toumbourou, J. (2004). Civic responsibility among Australian adolescents: Testing two competing models. Journal of Community Psychology, 32(3), 229-255. doi:10.1002/jcop. 20004

Fielding, K. S., McDonald, R., \& Louis, W. R. (2008). Theory of planned behavior, identity and intentions to engage in environmental activism. Journal of Environmental Psychology, 28(4), 318-326. doi:10.1016/j.jenvp.2008.03.003

Finlay, A. K., Wray-Lake, L., \& Flanagan, C. A. (2010). Civic engagement during the transition to adulthood: Developmental opportunities and social policies at a critical juncture. In L. R. Sherrod, J. Torney-Purta \& C. A. Flanagan (Eds.), Handbook of research on civic engagement in youth (pp. 277-305). Hoboken, NJ: Wiley.

Fischer, A., \& Kohr, H. (2002). Politisches Engagement [Political engagement]. In A. Glöckner-Rist (Ed.), ZUMA Informationssystem. Elektronisches Handbuch Sozialwissenschaftlicher Erhebungsinstrumente (Version 6.00). Mannheim, Germany: Zentrum für Umfragen, Methoden und Analysen.

Fishbein, M., \& Ajzen, I. (2010). Predicting and changing behavior: The reasoned action approach. New York, NY: Psychology Press.
Fletcher, A. C., Elder, G. H., \& Mekos, D. (2000). Parental influences on adolescent involvement in community activities. Journal of Research on Adolescence, 10(1), 29-48. doi:10.1207/SJRA1001_2

Fox-Cardamone, L., Hinkle, L. S., \& Hogue, M. (2000). The correlates of antinuclear activism: Attitudes, subjective norms, and efficacy. Journal of Applied Social Psychology 30(3), 484-498. doi:10. 1111/j.1559-1816.2000.tb02492.x

Gastil, J., \& Xenos, M. (2010). Of attitudes and engagement: Clarifying the reciprocal relationship between civic attitudes and political participation. Journal of Communication, 60(2), 318-343. doi:10.1111/ j.1460-2466.2010.01484.x

Glasford, D. E. (2008). Predicting voting behavior of young adults: The importance of information, motivation, and behavioral skills. Journal of Applied Social Psychology, 38(11), 2648-2672. doi: 10.1111/j.1559-1816.2008.00408.x

Gniewosz, B., \& Noack, P. (2006). Intergenerationale Transmissionsund Projektionsprozesse intoleranter Einstellungen zu Ausländern in der Familie [Intergenerational transmission and projection processes of anti-foreigner attitudes in family]. Zeitschrift für Entwicklungspsychologie und Pädagogische Psychologie, 38(1), 33-42. doi:10.1026/0049-8637.38.1.33

Graham, J. (2009). Missing data analysis: Making it work in the real world. Annual Review of Psychology, 60(1), 549-576. doi:10. 1146/annurev.psych.58.110405.085530

Hess, D. E. (2009). Controversy in the classroom: The democratic power of discussion. New York, NY: Routledge.

Jeličič, H., Phelps, E., \& Lerner, R. M. (2009). Use of missing data methods in longitudinal studies: The persistence of bad practices in developmental psychology. Developmental Psychology, 45(4), 1195-1199. doi:10.1037/a0015665

Jülisch, B. R. (1996). Zwischen Engagement, Apathie und Resignation: Politische Orientierungen Jugendlicher in Ost- und West-Berlin [Between engagement, apathy, and resignation: Political orientations of young people in East and West Berlin]. In J. Mansel \& A. Klocke (Eds.), Die Jugend von heute: Selbstanspruch, Stigma und Wirklichkeit (pp. 69-87). Weinheim, Germany: Juventa.

Kelly, C., \& Breinlinger, S. (1995). Attitudes, intentions, and behavior: A study of women's participation in collective action. Journal of Applied Social Psychology, 25(16), 1430-1445. doi:10.1111/j. 1559-1816.1995.tb02625.x

Krampen, G. (1998). Vorhersage politischer Partizipation und Entwicklung politischer Handlungsorientierungen im Übergang vom Jugend- zum frühen Erwachsenenalter [The prediction of political participation and the development of political action orientations in the transition from adolescence to young adulthood]. Zeitschrift für Entwicklungspsychologie und Pädagogische Psychologie, 30(2), 80-88.

Kroger, J. (2007). Identity development: Adolescence through adulthood (2nd ed.). Thousand Oaks, CA: SAGE.

Kuhn, H. P. (2010). International perspectives on political socialization and gender: An introduction. In A. Ittel, H. Merkens, L. Stecher \& J. Zinnecker (Eds.), Jahrbuch Jugendforschung 8 (2008/2009) (pp. 11-24). Wiesbaden, Germany: VS Verlag für Sozialwissenschaften.

Little, T. D., Cunningham, W. A., Shahar, G., \& Widaman, K. F. (2002). To parcel or not to parcel: Exploring the question, weighing the merits. Structural Equation Modeling, 9(2), 151-173. doi:10. 1207/S15328007SEM0902_1

Marzana, D., Marta, E., \& Pozzi, M. (2012). Social action in young adults: Voluntary and political engagement. Journal of Adolescence, 35(3), 497-507. doi:10.1016/j.adolescence.2011.08.013 
Muthén, L. K., \& Muthén, B. O. (1998-2010). Mplus user's guide: Statistical analysis with latent variables. Los Angeles, CA: Muthén \& Muthén.

Netemeyer, R. G., \& Burton, S. (1990). Examining the relationship between voting behavior, intention, perceived behavioral control, and expectation. Journal of Applied Social Psychology, 20(8), 661-680. doi:10.1111/j.1559-1816.1990.tb00431.x

Niemi, R. G., Craig, S. C., \& Mattei, F. (1991). Measuring internal political efficacy in the 1988 national election study. American Political Science Review, 85(4), 1407-1413. doi:10.2307/1963953

Oswald, H., \& Schmid, C. (2006). The influence of parents and peers on political participation of adolescents in the New States of Germany. In A. Sliwka, M. Diedrich \& M. Hofer (Eds.), Citizenship education. Theory - research - practice (pp. 85-96). Münster, Germany: Waxmann.

Pancer, M. S., Pratt, M., Hunsberger, B., \& Alisat, S. (2007). Community and political involvement in adolescence: What distinguishes the activists from the uninvolved? Journal of Community Psychology, 35(6), 741-759. doi:10.1002/jcop.20176

Pasek, J., Feldman, L., Romer, D., \& Jamieson, K. H. (2008). Schools as incubators of democratic participation: Building long-term political efficacy with civic education. Applied Development Science, 12(1), 26-37. doi:10.1080/10888690801910526

Richardson, W. K. (2003). Connecting political discussion to political engagement: The role of civic knowledge, efficacy and context for adolescents. Dissertation Abstracts International, 64(9-A), 3193.

Sameroff, A. (2010). A unified theory of development: A dialectic integration of nature and nurture. Child Development, 81(1), 6-22. doi: 10.1111/j.1467-8624.2009.01378.x

Sears, D. O., \& Levy, S. (2003). Childhood and adult political development. In D. O. Sears, L. Huddy \& R. Jervis (Eds.), Oxford handbook of political psychology (pp. 60-109). Oxford, UK: Oxford University Press.

Silbereisen, R. K. (2005). Social change and human development: Experiences from German unification. International Journal of Behavioral Development, 29(1), 2-13. doi:10.1080/01650250444000478

Sylvester, D. (2010). Service learning as a vehicle for promoting student political efficacy. Journal for Civic Commitment, 16(1), 1-10.

Syvertsen, A. K., Wray-Lake, L., Flanagan, C. A., Osgood, D. W., \& Briddell, L. (2011). Thirty-year trends in U.S. adolescents' civic engagement: A story of changing participation and educational differences. Journal of Research on Adolescence, 21, 586-594. doi:10. 1111/J. 1532-7795.2010.00706.x

Torney-Purta, J., Lehmann, R., Oswald, H., \& Schulz, W. (2001). Citizenship and education in twenty-eight countries: Civic knowledge at age fourteen. Amsterdam, The Netherlands: IEA.

Vecchione, M., \& Caprara, G. V. (2009). Personality determinants of political participation: The contribution of traits and self-efficacy beliefs. Personality and Individual Differences, 46(4), 487-492. doi:10.1016/j.paid.2008.11.021

Verba, S., Schlozman, K. L., \& Burns, N. (2005). Family ties: Understanding the intergenerational transmission of participation. In A. S. Zuckerman (Ed.), The social logic of politics: Personal networks as contexts for political behavior (pp. 95-114). Philadelphia, PA: Temple University Press.

Westholm, A. (1999). The perceptual pathway: Tracing the mechanisms of political value transfer across generations. Political Psychology, 20(3), 525-551. doi:10.1111/0162-895X.00155

Weßels, B. (2008). Politische Integration und politisches Engagement [Political integration and political engagement]. In Statistisches Bundesamt, Wissenschaftszentrum Berlin für Sozialforschung, Zentrum für Umfragen \& Methoden und Analysen (Eds.), Datenreport 2008: Ein Sozialbericht für die Bundesrepublik Deutschland (pp. 391-396). Bonn, Germany: Bundeszentrale für politische Bildung.

Wilkenfeld, B., Lauckhardt, J., \& Torney-Purta, J. (2010). The relation between developmental theory and measures of civic engagement in research on adolescents. In L. R. Sherrod, J. Torney-Purta \& C. A. Flanagan (Eds.), Handbook of research on civic engagement in youth (pp. 193-219). Hoboken, NJ: Wiley.

Zaff, J. F., Malanchuk, O., \& Eccles, J. S. (2008). Predicting positive citizenship from adolescence to young adulthood: The effects of a civic context. Applied Developmental Science, 12(1), 38-53. doi: 10.1080/10888690801910567

\section{Appendix}

Item wording of scale attitudes toward political behaviors (adopted from Fischer \& Kohr, 2002):

1. There are not too many, but too few people politically active in Germany.

2. Somebody who complains about political parties should join a party to change it.

3. We should take the chance to participate in politics.

4. We should participate more in politics to influence political decisions.

Item wording of scale important others' attitudes toward political behaviors (adopted from Ajzen, 2002a):

1. Most people who are important to me don't care whether I am politically engaged.

2. Most people who are important to me think that it is important to participate in politics.

3. People in my life whose opinions I value would approve, if I were politically engaged.

4. Many people who are important to me approve of political engagement.

Item wording of scale internal political efficacy (adopted from Niemi et al., 1991):

1. I feel that I have a pretty good understanding of the important political issues facing our country.

2. I consider myself well qualified to participate in politics.

3. I think that I am better informed about politics and government than most people.

4. I feel I could do as good a job in public office as most other people.

Item wording of scales intentions to participate in politics and actual political behaviors:

1. I would work for a political party. / I have already worked for a political party.

2. I would support a political candidate during an election campaign. / I have already supported a political candidate during an election campaign.

3. I would visit political debates or campaign events. / I have already visited political debates or campaign events.

4. I would contact politicians (for example via mail or e-mail). / I have already contacted politicians (for example via mail or email). 